\title{
Frequency of Spinocerebellar Ataxia type 1, 2, 3,6 and 7 and clinical profile of Spinocerebellar Ataxia type 3 in Malaysia
}

\author{
Norlinah Mohamed Ibrahim ${ }^{1 *+} \mathbb{D}$, Yue Hui Lau ${ }^{2 \dagger}$, Noorasyikin Ariffin ${ }^{3}$, Siti Hajar Md Desa ${ }^{1}$, Elena Azizan ${ }^{4}$, \\ Long Kha Chin ${ }^{4}$, Shahrul Azmin Md Rani ${ }^{1}$, Yusnita Yakob ${ }^{5}$, Santhi Datuk Puvanarajah² and \\ Bart van de Warrenburg ${ }^{6}$
}

\begin{abstract}
Spinocerebellar ataxias (SCA) are highly heterogenous group of neurodegenerative diseases causing progressive cerebellar dysfunction. We report the first description of relative frequencies of the common SCA mutations and of phenotypic characteristics of SCA3 patients among Malaysians. Pooled data from adult Malaysian patients who had undergone genetic testing for SCA 1,2,3,6 and 7 at UKM Medical Centre and Institute for Medical Research from 2017 to 2020 were analysed. Fifteen patients with SCA 3 had detailed clinical phenotype evaluation using Inventory for Non -Ataxia Signs (INAS) and Ataxia Severity evaluation using the Scale for Assessment and Rating of Ataxia (SARA). Out of 152 adults patients who were tested for common SCA mutations, 64(42.1\%) patients were tested positive for either SCA 1,2,3,6 or 7. Of the 64 positive cases, 44 (68.9\%) patients were diagnosed with SCA 3 followed by SCA 2 in 13(20.3\%) patients and SCA 1 in 5 (7.8\%) patients. Our findings suggest that Malay race had the highest frequency of SCA $(n=34,50 \%)$, followed by the Chinese $(n=16,23.5 \%)$ and approximately $60(93.8 \%)$ SCA patients had first degree family history. In conclusion, SCA 3 is the commonest SCA in Malaysia, followed by SCA 2 and SCA 1. It is important to develop a proper registry of SCA patients to further understand the true prevalence and local impact of the disease in Malaysia.
\end{abstract}

\section{Brief report}

Spinocerebellar ataxias (SCA) are autosomal dominant, neurodegenerative disorders causing mostly adult-onset, progressive cerebellar dysfunction, with or without involvement of other central and peripheral nervous system components. To date, there are almost 50 genetic SCA subtypes worldwide [1], with SCAs 1, 2, 3, 6 and 7 being the commonest $[1,2]$. The phenotypic characteristics of SCAs are heterogeneous with wide intrafamilial and interfamilial variability $[3,4]$. While the prevalence

\footnotetext{
*Correspondence: norlinah@ppukm.ukm.edu.my; norlinah@gmail.com ${ }^{\dagger}$ Norlinah Mohamed Ibrahim and Yue Hui Lau contributed equally to this work.

${ }^{1}$ Neurology Unit, Department of Medicine, Universiti Kebangsaan Malaysia Medical Centre, Kuala Lumpur, Malaysia

Full list of author information is available at the end of the article
}

of SCA is established in many Western countries $[1,3]$ and some East Asian countries such as China [5] and Korea [6], data on SCA in the South East Asian countries is lacking apart from two published studies from Thailand [7] and Singapore [8], there is no data on SCA in other countries within this region, possibly due to lack of testing facilities locally. Since 2017, two centres (UKM Medical Center and Institute for Medical Research (IMR), Malaysia) in Malaysia have provided genetic testing for SCA1, 2, 3, 6 and 7, which enabled identification of cases with one of these more common SCA subtypes. UKM Medical Center is a tertiary referral center, which provides diagnosis and clinical management of SCA in Malaysia, whereas IMR is a laboratory testing facility which receives patient samples for SCA 
genetic testing from other centers throughout Malaysia. Malaysia is a multi-ethnic country with a population of 32.6 million (2019), of which 3.2 million are noncitizens. The major ethnic group is Malay (69.3\%) followed by Chinese (22.8\%), Indians (6.9\%) and natives (1\%). Here, we report the first description of relative frequencies of the common SCA mutations and of phenotypic characteristics of SCA3 patients among Malaysian adults.

The frequency analysis was conducted as part of audit review using data of Malaysian patients, aged 18 and above who had undergone genetic testing for SCA1, 2, 3, 6 and 7 at UKM Medical Centre, Kuala Lumpur and Institute for Medical Research, Kuala Lumpur from February 2017 to February 2020. Non-Malaysian patients who had tested positive were excluded. Data on age, race, family history and age of testing were available for analysis. Genetic analysis was performed in UKMMC and IMR using both standard PCR and triplet-primed PCR techniques respectively.

Clinical profile evaluation for SCA 3 using the Inventory for Non-Ataxia Signs (INAS) [9] and the Scale for Assessment and Rating of Ataxia (SARA) [10] were available separately for fifteen SCA 3 patients who were enrolled in another clinical study on SCA 3 in UKM Medical Center [11]. Ethical approval was obtained from the institution's Ethics Committee (FF-2018-082).

Out of 152 patients who had undergone genetic testing from 2017 to 2020, 64 (42.1\%) patients tested positive for either SCA1, 2, 3 or 6 . Of these 64 positive cases, SCA3 was the commonest, detected in 44 (68.9\%) patients, followed by SCA2 in $13(20.3 \%)$ and SCA1 in 5 $(7.8 \%)$ and SCA6 in 2(3\%). None of the patients were tested positive for SCA 7 (Table 1). A positive family

Table 1 Demographics of patients with Spinocerebellar Ataxia Type 1, 2, 3, 6 and 7 in Malaysia

\begin{tabular}{|c|c|c|c|c|c|}
\hline $\begin{array}{l}\text { Type of SCAs } \\
(n, \%)\end{array}$ & $\begin{array}{l}\text { SCA } 1 \\
5(7.8 \%)\end{array}$ & $\begin{array}{l}\text { SCA } 2 \\
13(20.3 \%)\end{array}$ & $\begin{array}{l}\text { SCA } 3 \\
44(68.9 \%)\end{array}$ & $\begin{array}{l}\text { SCA } 6 \\
2(3 \%)\end{array}$ & $\begin{array}{l}\text { SCA } 7 \\
0(0)\end{array}$ \\
\hline \multicolumn{6}{|l|}{ Gender (n, \%) } \\
\hline Male & $2(3)$ & $9(14.2)$ & $22(34.4)$ & $2(3)$ & $0(0)$ \\
\hline Female & $3(4.7)$ & $4(6.3)$ & $22(34.4)$ & $0(0)$ & $0(0)$ \\
\hline \multicolumn{6}{|l|}{ Ethnicity (n, \%) } \\
\hline Malay & $0(0)$ & $10(15.6)$ & $24(37.5)$ & $0(0)$ & $0(0)$ \\
\hline Chinese & 1 (1.6) & $1(1.6)$ & $13(20.3)$ & $2(3)$ & $0(0)$ \\
\hline Indian & $3(4.7)$ & $1(1.6)$ & $3(4.7)$ & $0(0)$ & $0(0)$ \\
\hline Punjabi & $0(0)$ & $0(0)$ & $4(6.3)$ & $0(0)$ & $0(0)$ \\
\hline Others & $1(1.6)$ & 1 (1.6) & $0(0)$ & $0(0)$ & $0(0)$ \\
\hline \multicolumn{6}{|c|}{ Family history (n, \%) } \\
\hline Yes & $4(6.3)$ & $11(17)$ & $44(68.9)$ & $1(1.6)$ & - \\
\hline No & - & $1(1.6)$ & - & $1(1.6)$ & - \\
\hline Unknown & $1(1.6)$ & $1(1.6)$ & - & - & - \\
\hline
\end{tabular}

history in a first degree relative was present in 60 out 64 patients $(93.8 \%)$, while $3(4 \%)$ cases were sporadic, and for the remaining 7 patients' data on family history were incomplete. SCA3 affected all races including Malays. There was no ethnic preponderance for any of the SCAs tested. Consistent with the ethnic composition of the

Table 2 Clinical and phenotypic characteristics of SCA 3 patients in Malaysia using INAS

\begin{tabular}{|c|c|}
\hline \multicolumn{2}{|l|}{ Baseline characteristics $(n=15)$} \\
\hline \multicolumn{2}{|l|}{ Gender: } \\
\hline Male (n, \%) & $9.0(60.0 \%)$ \\
\hline Female (n, \%) & $6.0(40.0 \%)$ \\
\hline Mean age of presentation (years,(SD)) & $35.6( \pm 9.2)$ \\
\hline Mean age of onset (years, (SD) & $31.2( \pm 8.1)$ \\
\hline Mean duration of illness (years, (SD)) & $4.5( \pm 2.9)$ \\
\hline Median time to wheel chair (months, (IQR)) & $12.0(12.0-24.0)$ \\
\hline Median time to ophthalmoplegia (months, IQR)) & $12.0(6.0-21.0)$ \\
\hline Mean SARA at baseline score (score (SD)) & $12.3( \pm 8.9)$ \\
\hline \multicolumn{2}{|l|}{ Phenotypic Characteristics (n, \%) } \\
\hline Broken smooth pursuit & $7(46.7)$ \\
\hline Square jerk fixation & $7(46.7)$ \\
\hline Downbeat nystagmus & $4(26.7)$ \\
\hline Gaze evoked horizontal nystagmus & 8(53.3.) \\
\hline Gaze evoked vertical nystagmus & $3(20.0)$ \\
\hline Ophthalmoparesis on horizontal nystagmus & $7(46.7)$ \\
\hline Opthalmoparesis vertical gaze & $7(46.7)$ \\
\hline Slowing saccades & $7(46.7)$ \\
\hline Hypermetric saccades & $3(20.0)$ \\
\hline Hypometric saccades & $7(46.7)$ \\
\hline Diplopia & $7(46.7)$ \\
\hline Ophthalmoplegia & $7(46.7)$ \\
\hline Hyperreflexia & $9(60.0)$ \\
\hline Extensor plantar reflex & $3(20.0)$ \\
\hline Clonus & $2(13.3)$ \\
\hline Spasticity & $6(40.0)$ \\
\hline Rigidity & $2(13.3)$ \\
\hline Resting tremor & $0(0)$ \\
\hline Dystonia & $2(13.3)$ \\
\hline Paresis & $0(0)$ \\
\hline Muscle atrophy & $2(13.3)$ \\
\hline Fasciculation & $2(13.3)$ \\
\hline Chorea & $0(0)$ \\
\hline Impaired vibration sense & $1(6.7)$ \\
\hline Dysarthria & 14(93.3) \\
\hline Dysphagia & $3(20.0)$ \\
\hline Cognitive impairment & $1(6.7)$ \\
\hline
\end{tabular}


Malaysian population, the majority of SCA mutation carriers were Malay $(n=34,50 \%)$, followed by Chinese $(n=16,23.5 \%)$ (Table 1).

In 15 patients with SCA3 whose clinical profile was evaluated, the mean age of onset was $31.2 \pm 8.1$ years and the mean age of presentation was $35.6 \pm 9.2$ years. The mean SARA score was $12.3 \pm 8.9$. The CAG repeats expansion ranged, 68 to 83, with a mean CAG repeat expansion of $74 \pm 4$. A cerebellar syndrome was present in $100 \%$ of the cases, pyramidal signs in $60 \%$, parkinsonism in $13 \%$, and dystonia in $13 \%$. Ocular manifestations such as nystagmus, ophthalmoplegia, and saccadic abnormalities were common in SCA3 patients, affecting up to $50 \%$ of patients. Detailed phenotypic characteristics based on INAS are presented in Table 2 .

Similar to worldwide data, SCA3 was the commonest SCA in Malaysia, followed by SCA2 and SCA1, whereas SCA6 and SCA7 were the least common. Except for Korea [6] and India [12] where SCA2 was the commonest, other Asian countries have reported SCA3 to be the commonest. A study conducted in Thailand also reported that SCA3 was the commonest, followed by SCA1, SCA2 and SCA6 [7]. Similar to our findings, a Singapore study reported that SCA3 was the commonest, followed by SCA2. They also reported that SCA2 affected the Malay ethnic group exclusively [8]. However, our data showed that SCA2 affected all races and did not affect the Malay ethnic group exclusively, despite a similar ethnic composition to Singapore. Apart from these two studies $[7,8]$ there is no published data on the prevalence of SCA in other South East Asian countries. As expected, there was a high diagnostic yield of $93.8 \%$ in patients with a positive family history, but we also identified sporadic presentations of SCAs. The clinical phenotype of patients with SCA3 was similar to that reported in other countries $[3,4]$, with a predominant cerebellar syndrome with prominent pyramidal signs in $60 \%$ and extrapyramidal signs in $26 \%$. One important limitation of this study is that we were unable to account for those who had their genetic testing done elsewhere, which could have led some inaccuracies in the relative frequencies calculated. Still, this study is the first to report the frequency of common SCAs in Malaysia, which could be used as a stepping stone in conducting a large-scale epidemiological study on SCA in Malaysia. We believe the availability and the relatively lower cost of genetic testing locally had increased the number of tests conducted. As data on SCA in the South East Asian regions is still lacking, there is a need for collaborative efforts among experts to look into the challenges and priorities in the detection and management of SCA in this region. Facilitating diagnosis, with a proper registry are key in enhancing the care and comprehensive management of SCA patients within this region, and to include patients in future trials.

\section{Acknowledgements}

The authors thank Ministry of Health Malaysia for the administrative. assistance. The study is part of ongoing activities as a result of Memorandum of Understanding between Universiti Kebangsaan Malaysia and Radboud University Medical Center.

\section{Financial disclosures}

There are no financial disclosures to report.

\section{Funding sources}

BvdW is supported by grants from Radboud university medical centre, Gossweiler Foundation, Hersenstichting, ZonMW, and uniQure.

\section{Authors' contributions \\ 1. Conception and Design: NMI, BvdW. 2. Execution: YHL, NMI, NA, YY, EA, LKC, SHMD, SAR. 3. Critical Analysis and Revision: YHL, NMI, BvdW, SDP. 4. Final approval: All authors.}

\section{Availability of data and materials}

The datasets used and/or analysed during the current study are available from the corresponding author on reasonable request.

\section{Ethics approval and consent to participate}

Ethical approval was obtained from the Universiti Kebangsaan Malaysia Medical Research Ethics Committee (FF-2018-082). Consent to use data was obtained from was required from the Head of Molecular Diagnostic Laboratory Services, IMR, Ministry of Health, Malaysia and the Director of UKM Medical Center.

\section{Consent for publication}

Consent is obtained from all the relevant parties.

\section{Competing interests}

There is no competing interest to report.

\section{Author details}

${ }^{1}$ Neurology Unit, Department of Medicine, Universiti Kebangsaan Malaysia Medical Centre, Kuala Lumpur, Malaysia. ${ }^{2}$ Neurology Department, Hospital Kuala Lumpur, Kuala Lumpur, Malaysia. ${ }^{3}$ Department of Medicine, Hospital Labuan, Wilayah Persekutuan, Malaysia. ${ }^{4}$ Molecular Laboratory, Department of Medicine, Universiti Kebangsaan Malaysia Medical Centre, Kuala Lumpur, Malaysia. ${ }^{5}$ Molecular Genetics Department, Institute of Medical Research, Kuala Lumpur, Malaysia. ${ }^{6}$ Department of Neurology, Donders Institute of Brain, Cognition, and Behaviour, Radboud University Medical Center, Nijmegen, Netherlands.

Received: 26 July 2020 Accepted: 28 July 2020

Published online: 03 August 2020

\section{References}

1. Huang M, Verbeek DS. Why do so many genetic insults lead to Purkinje cell degeneration and spinocerebellar ataxia? Neurosci Lett. 2018;S03043940(18):30080-6. https://doi.org/10.1016/j.neulet.2018.02.004.

2. Sullivan $\mathrm{R}$, Yau WY, O'Connor $\mathrm{E}$, Houlden $\mathrm{H}$. Spinocerebellar ataxia: an update. J Neurol. 2019;266:533-44.

3. Jacobi $H$, Bauer $P$, Giunti $P$, Labrum $R$, Sweeney MG, Charles $P$, Dürr A Marelli C, Globas C, Linnemann C, Schöls L, Rakowicz M, Rola R, Zdzienicka E, Schmitz-Hübsch T, Fancellu R, Mariotti C, Tomasello C, Baliko L, Melegh B, Filla A, Rinaldi C, van de Warrenburg BP, Verstappen CCP, Szymanski S, Berciano J, Infante J, Timmann D, Boesch S, Hering S, Depondt C, Pandolfo M, Kang JS, Ratzka S, Schulz J, Tezenas du Montcel S, Klockgether T. The natural history of spinocerebellar ataxia type 1, 2, 3, and 6: a 2-year followup study. Neurology. 2011;77:1035-41.

4. Teive HAG, Munhoz RP, Arruda WO, Lopes-Cendes I, Raskin S, Werneck LC, Ashizawa T. Spinocerebellar ataxias: genotype-phenotype correlations in 104 Brazilian families. Clinics (Sao Paulo, Brazil). 2012;67:443-9.

5. Tang B, Liu C, Shen L, Dai H, Pan Q, Jing L, Ouyang S, Xia J. Frequency of SCA1, SCA2, SCA3/MJD, SCA6, SCA7, and DRPLA CAG Trinucleotide repeat expansion in patients with hereditary Spinocerebellar Ataxia in patients from Chinese Kindreds. Arch Neurol. 2000;57:540-4. 
6. Kim H-J, Jeon BS, Lee WY, Chung SJ, Yong SW, Kang JH, Lee S-H, Park K-W Park MY, Kim BC, Kim JW, Kim H-T, Ha CK, Koh S-B, Kim J-M, Choi K-D, Sung Y-H, Ahn T-B, Lee G-H, Lee JH, Lee H-W, Kim SJ, Park J-H, Kwon D-Y, Kim MJ, Kim YJ, Kim J-S, Cho J, Kwon J-H, Kim E-J, Kim JH, Sung K-B, Song I-U, Oh H-G, Lee S-B, Lee S-H, Lee J-Y, Lee T-K, Cho AH, Yoon WT, Kim SR, Kim HJ. SCA in Korea and its regional distribution: a multicenter analysis. Parkinsonism Relat Disord. 2011;17:72-5.

7. Boonkongchuen P, Pongpakdee S, Jindahra P, Papsing C, Peerapatmongkol P, Wetchaphanphesat S, Paiboonpol S, Dejthevaporn C, Tanprawate S, Nudsasarn A, Jariengprasert C, Muntham D, Ingsathit A, Pulkes T. Clinical analysis of adult-onset spinocerebellar ataxias in Thailand. BMC Neurol. 2014;14:75.

8. Zhao Y, Tan E, Law H, Yoon C, Wong M, Ng I. Prevalence and ethnic differences of autosomal-dominant cerebellar ataxia in Singapore. Clin Genet. 2002:62:478-81.

9. Jacobi H, Rakowicz M, Rola R, Fancellu R, Mariotti C, Charles P, Dürr A, Küper M, Timmann D, Linnemann C, Schöls L, Kaut O, Schaub C, Filla A, Baliko L, Melegh B, Kang JS, Giunti P, van de Warrenburg BPC, Fimmers R, Klockgether T. Inventory of non-Ataxia signs (INAS): validation of a new clinical assessment instrument. Cerebellum. 2013;12:418-28.

10. Schmitz-Hübsch T, du Montcel ST, Baliko L, Berciano J, Boesch S, Depondt C, Giunti P, Globas C, Infante J, Kang J-S, Kremer B, Mariotti C, Melegh B, Pandolfo M, Rakowicz M, Ribai P, Rola R, Schöls L, Szymanski S, van de Warrenburg BP, Dürr A, Klockgether T. Scale for the assessment and rating of ataxia. Dev New Clin Scale. 2006;66:1717-20.

11. Noorasyikin MA, Azizan EA, Teh PC, Farah Waheeda T, Siti Hajar MD, Long KC, Norlinah MI. Oral trehalose maybe helpful for patients with spinocerebellar ataxia 3 and should be better evaluated. Parkinsonism Relat Disord. 2020;70:42-4.

12. Sinha KK, Worth PF, Jha DK, Sinha S, Stinton VJ, Davis MB, Wood NW, Sweeney MG, Bhatia KP. Autosomal dominant cerebellar ataxia: SCA2 is the most frequent mutation in eastern India. J Neurol Neurosurg Psychiatry. 2004:75:448-52.

\section{Publisher's Note}

Springer Nature remains neutral with regard to jurisdictional claims in published maps and institutional affiliations.

Ready to submit your research? Choose BMC and benefit from:

- fast, convenient online submission

- thorough peer review by experienced researchers in your field

- rapid publication on acceptance

- support for research data, including large and complex data types

- gold Open Access which fosters wider collaboration and increased citations

- maximum visibility for your research: over $100 \mathrm{M}$ website views per year

At $\mathrm{BMC}$, research is always in progress.

Learn more biomedcentral.com/submissions 